\title{
Physico-chemical and immunological observations on the abnormal proteins in three patients with cryoglobulinaemia
}

\author{
H. A. ELLIS AND D. R. STANWORTH \\ With the technical assistance of \\ P. RATCLIFF
}

From the Department of Experimental Pathology, University of Birmingham

SYNOPSIS Three new cases of cryoglobulinaemia are described, and in each case the presence of the cryoglobulin appeared to be unrelated to the clinical manifestations. Although when examined by paper electrophoresis the abnormal proteins behaved uniformly as normal gamma globulins, marked differences in nature were revealed when ultracentrifugal and immunological analyses were made. One patient had an abnormal protein which behaved both as a cryoglobulin and as a macroglobulin.

Abnormalities in the serum proteins may be quantitative or qualitative in nature. In the latter instance, certain globulins normally absent, or possibly present in trace amounts, are found in high concentrations. This group of protein disorders includes the myeloma proteins, macroglobulins, and cryoglobulins. The present paper is concerned with this last type of protein and three new cases are described.

The term cryoglobulin was introduced by Lerner and Watson (1947) to describe any protein which precipitated from whole serum on cooling and redissolved on subsequent warming. These writers described such an occurrence in the serum from a patient with purpura and referred to nine cases previously reported in the literature. It appears that Wintrobe and Buell (1933) first observed this phenomenon in a case of myelomatosis. Cryoglobulins have been found in a wide variety of pathological conditions: liver disease (Atlas, Cardon, and Bunata, 1943), kala azar, bacterial endocarditis, malaria, and chronic nephritis (Wertheimer and Stein, 1944).

Shapiro and Wertheimer (1946) first described cryoglobulinaemia in a patient suffering from polyarteritis nodosa. Lepow, Rubenstein, Woll, and Greisman (1949) described two further cases, and more recently Dreyfuss (1953) observed cryoglobulins in two cases of polyarteritis nodosa, whilst Butler and Palmer (1955) described a further case. One of

Received for publication 28 May 1960. the present patients suffered from polyarteritis nodosa.

For a detailed historical review, the reader is referred to the paper by Mackay, Eriksen, Motulksy, and Volwiler (1956) in which proved published cases of cryoglobulinaemia, up to that time, are analysed, 21 occurring in multiple myelomatosis and 32 in miscellaneous disorders.

\section{CASE REPORTS}

CASE 1: CRYOGLOBULINAEMIA IN A CASE OF POLYARTERITIS NODOSA A 22-year-old woman was admitted to the Queen Elizabeth Hospital, Birmingham, under the care of Dr. C. F. Hawkins, in November 1956, with a threeweek history of headache, vomiting, and pyrexia. The urine contained protein, red cells, and granular casts. It was thought initially that the patient was suffering from acute nephritis and during the course of an examination of the serum for complement activity, one of us noted the presence of a cryoglobulin. Splenomegaly and bilateral pleural effusions subsequently developed, the patient became uraemic and died as a result of a pulmonary embolus. Post-mortem (Dr. P. V. Best) and histological examinations confirmed the diagnosis of polyarteritis nodosa. Typical lesions were present in the liver, kidneys, and suprarenals. In addition there was a single encysted Trichinella spiralis larva in the tongue.

CASE 2: CRYOGLOBULINAEMIA IN A CASE OF STEATORRHOEA A 63-year-old man was admitted to the General Hospital, Birmingham, under the care of Dr. W. T. Cooke, in February 1958. The patient had been first seen in 1957 179 
with a history of recurrent abdominal pain for many years. A laparotomy undertaken elsewhere in 1952 failed to reveal a cause for the symptoms. He had suffered from intermittent diarrhoea and the stools had been pale on occasions. He had an anaemia (haemoglobin $8.7 \mathrm{~g}$. per $100 \mathrm{ml}$; $100 \%=14.8 \mathrm{~g}$.) and a granulocytic leucopenia (total white blood cell count 4,800 per c. mm., polymorphonuclear leucocytes $7 \%$ ).

At the time of admission the blood findings were confirmed and a marrow biopsy revealed a normoblastic erythropoiesis. The marrow contained a large number of plasma cells $(30 \%)$. There was no evidence of a myeloma type protein in the serum or urine, but a cryoglobulin was detected in the serum by the biochemist, Dr. B. Northam, during a routine examination. Radiological examination of the intestinal tract and bones revealed no abnormality. Examination of the stools revealed a high fat content, and over a six-day balance study between 7.8 and $15.7 \mathrm{~g}$. fat, with an average of $11.9 \mathrm{~g}$., was being excreted per 24 hours. This is well above the normal upper limit of $6 \mathrm{~g}$. per 24 hours (Cooke and French, 1958).

The possibility that this patient was suffering from cirrhosis was excluded by a liver biopsy which showed only mild fatty change. The Wassermann reaction was negative. A congo red test for amyloidosis also gave a negative result.

This patient was treated with A.C.T.H. and steroids have been continued since. There has been no change in the degree of cryoglobulinaemia or any significant improvement in the blood count, the total white cells varying between 2,000 and 3,800 per $\mathrm{c}$. $\mathrm{mm}$., with few polymorphonuclear leucocytes. This patient undoubtedly has steatorrhoea, but the significance of the raised plasma cell count in the marrow remains uncertain.

CASE 3: CRYOGLOBULINAEMIA IN A CASE OF LIVER DISEASE A 32-year-old male Pakistani was admitted to the General Hospital, Birmingham, under the care of Dr. P. Davison in May 1958, complaining of abdominal pain, weight loss, and fever. He had marked hepatosplenomegaly but no ascites. One of us detected a cryoglobulin in the serum while carrying out a complement estimation. Splenectomy was performed for hypersplenism, and the patient died following the development of a subphrenic abscess. The spleen weighed 2,025 g. Post-mortem and histological examinations (Dr. D. B. Brewer) indicated that cirrhosis of the liver was present, and the enlarged spleen had the changes associated with chronic congestion. There was no evidence of amyloidosis.

\section{MATERIALS AND METHODS}

Blood was collected in a warmed syringe from Cases 1 , 2 , and 3 . In addition a larger volume was obtained from the splenectomy specimen in Case 3.

Cryoglobulins were isolated by centrifugation of sera cooled to $4^{\circ} \mathrm{C}$. and then dissolved in $0.85 \%$ saline at $37^{\circ} \mathrm{C}$. Purification was attempted by repeating this process several times.

ESTIMATION OF SERUM PROTEINS BY PAPER ELECTROPHORESIS Total serum proteins were estimated by a
Biuret method, and individual components were separate $\Phi$ and studied quantitatively by the paper electrophoresis. technique described by Hardwicke (1954). Cryoglobulip⿱ concentrations were estimated from the differences it protein concentration of serum at $37^{\circ} \mathrm{C}$. and at $4^{\circ} \mathrm{C}$.

ULTRACENTRIFUGAL ANALYSIS Whole sera and isolate $\bar{\phi}$ cryoglobulins were analysed at 60,000 r.p.m. and $20^{\circ} \mathrm{C}$. in a Spinco model $\mathrm{E}$ machine incorporating a Philpotion Svensson optical system. Specimens were diluted to contain approximately $1.0 \mathrm{~g}$. protein per $100 \mathrm{ml}$. and dialysed for 16 hours against 1 litre of acetate buffer $(p H 4 \cdot 7 \overrightarrow{\mathrm{\omega}}$ $I=0 \cdot 10$ ), containing $0 \cdot 2 \mathrm{M}$. $\mathrm{NaCl}$, since cryoglobuling have been reported to be more soluble at low temperature in this medium (Gunz, 1956). Relative concentrations of the various ultracentrifugal components were estimated from the enlarged tracings of the Schlieren patterns.

IMMUNOLOGICAL STUDIES Serum complement estima tions were made as previously described (Walton an Ellis, 1958), using fresh sera.

Gel-diffusion precipitin analyses were carried out wit rabbit antisera raised against Freund adjuvants of th cryoglobulins from Cases 2 and 3 , injected subcu aneously.

Immuno-electrophoretic analyses (Grabar an£ Williams, 1955) were carried out using specific antisera against normal human $\gamma$-globulin, as well as against two of the cryoglobulins.

RESULTS

In each instance the cryoglobulin precipitated out from the whole serum on cooling as a white flocculent precipitate. This process was reversible, the preci. pitate readily going into solution on warming $t \overline{\mathrm{Q}}$. $37^{\circ} \mathrm{C}$. The temperature at which precipitation occurred was between $28^{\circ} \mathrm{C}$. and $32^{\circ} \mathrm{C}$. in the case of the cryoglobulins from Cases 1 and 2, whereas that from Case 3 was only precipitated after the serurb had been allowed to stand at $4^{\circ} \mathrm{C}$. overnight.

Microscopical examination indicated the amor phous nature of the precipitate, and whether the precipitate was allowed to form slowly or rapidl there was no evidence of crystal formation, which: was described in a case by Shapiro and Wertheimen (1946).

PAPER ELECTROPHORESIS STUDIES Paper electró phoresis analyses of sera (Table $I$ and Fig. indicated that all three cryoglobulins were containes in the gamma globulin fraction. The cryoglobuli preparations obtained by cooling the sera were found, after purification, to be electrophoreticall homogeneous, except for the presence of a trace of albumin in that from Case 2.

ULTRACENTRIFUGAL ANALYSES Although paper elec trophoresis studies showed an apparent uniformito 

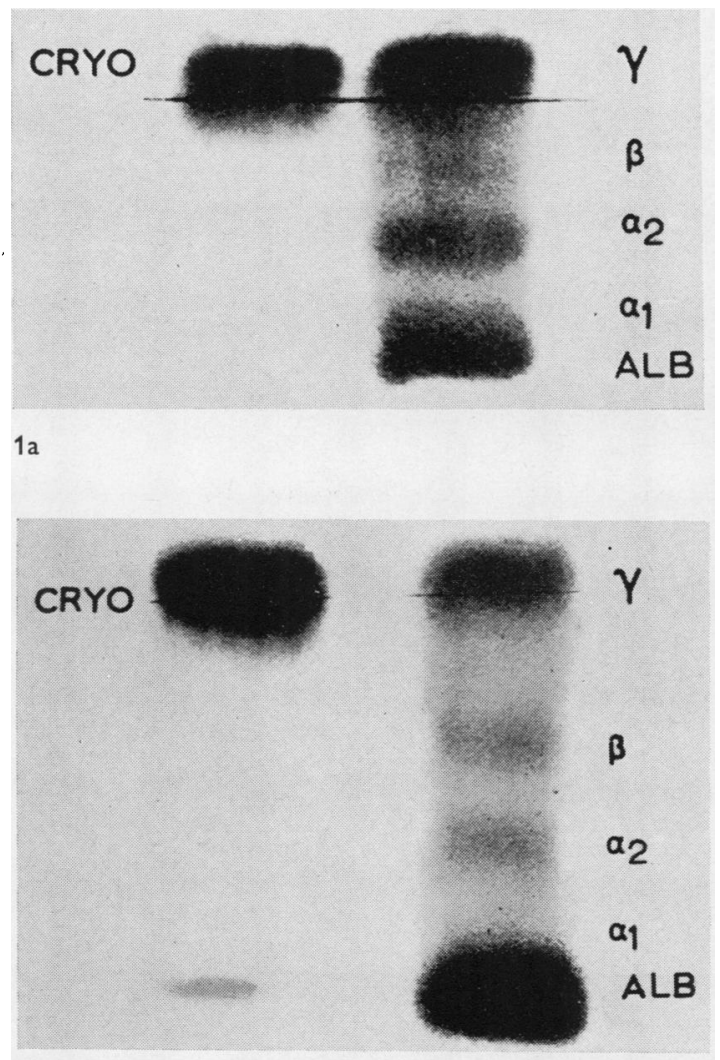

16

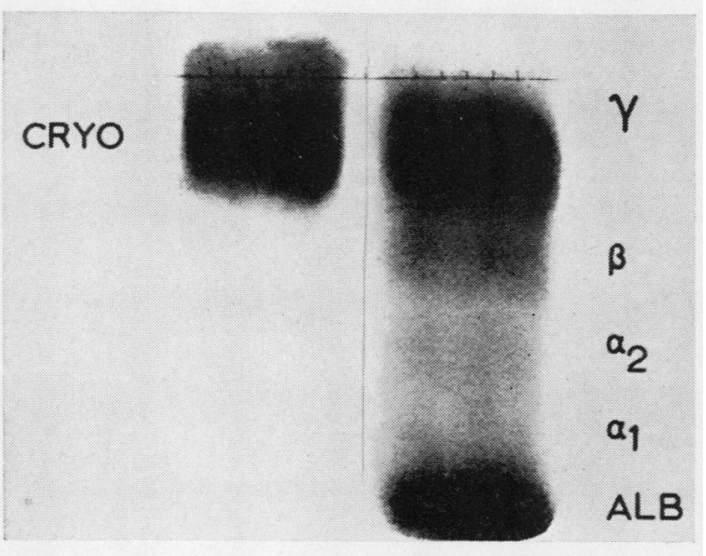

$1 c$

FIG. 1. (a) Case 1, (b) Case 2, (c) Case 3. Results of paper electrophoretic analyses of whole serum and isolated cryoglobulins from the three cases. $\left(\right.$ Alb $=$ Albumin; $a_{1}, a_{2}$, $\beta$, and $\gamma=$ normal globulin components; $C R Y O=$ cryoglobulin).
TABLE I

PAPER ELECTROPHORETIC ANALYSES OF SERA FROM 3 CASES OF CRYOGLOBULINAEMIA

\begin{tabular}{ccccccc} 
Case & \multicolumn{6}{l}{ Concentrations of Protein Components $(\mathrm{g} . \%)$} \\
\cline { 2 - 7 } & Albumin & $a^{1}$ & $a^{2}$ & $\beta$ & $\begin{array}{l}\text { Cryoglo- } \\
\text { bulin } \\
+\gamma\end{array}$ & $\begin{array}{l}\text { Cryoglo- } \\
\text { bulin } \\
\text { (estimated) }\end{array}$ \\
\hline 1 & 2.12 & 0.39 & 1.23 & 0.70 & 2.90 & 0.75 \\
2 & 3.03 & 0.52 & 0.86 & 0.87 & 1.83 & 1.15 \\
3 & 2.36 & 0.44 & 0.50 & 0.80 & 3.20 & 0.23
\end{tabular}

(The value for the cryoglobulin concentration was estimated from the difference in protein concentration of the serum before and after removal of the cryoglobulin.)

of the cryoglobulins, examination in the ultracentrifuge revealed marked differences. Only the preparation from Case 2 was found to possess a similar sedimentation coefficient (7S) to that of normal serum gamma globulin. As shown (Table II), one of the other preparations (Case 1) appeared to be composed entirely of lower molecular weight material (4.6S), whereas the third (Case 3) was largely composed of higher molecular weight protein (19S and 22S).

The ultracentrifugal patterns obtained (Fig. 2) indicate that, apart from the small amount of $22 \mathrm{~S}$ material detected in the cryoglobulin from Case 3, all the isolated proteins were composed of normal serum ultracentrifugal components. Contamination with non-cryoglobulin constituents (to the extent of 10 to $25 \%$ of the total protein concentration) seemed probable in the cryoglobulin preparations from the sera of Cases 2 and 3. The low concentration of protein in the solution of the cryoglobulin preparation from Case 1 diminished the chance of detecting similar contamination. Moreover, this specimen had been stored for several weeks at a low $p H$ (acetate buffer $p \mathrm{H} \mathrm{4.5)}$ before ultracentrifugal analysis, and it is possible that the cryoglobulin had been degraded. The sedimentation coefficient could not be determined with any high degree of accuracy because of the difficulty in establishing the mid-point of the very small Schlieren peak. It seems possible, therefore, that the cryoglobulin from Case 1 was originally associated with the abnormally high concentration of $7 \mathrm{~S}$ component found in the whole serum.

SERUM COMPLEMENT Serum complement was normal in the sera from Cases 2 and 3 and no anticomplementary activity could be detected. In contrast there was a marked depression in serum complement activity in the whole serum from Case 1 . There was a rise in activity in the serum after the cryoglobulin had been removed by centrifugation at $4^{\circ} \mathrm{C}$., and the washed cryoglobulin produced a depression of 

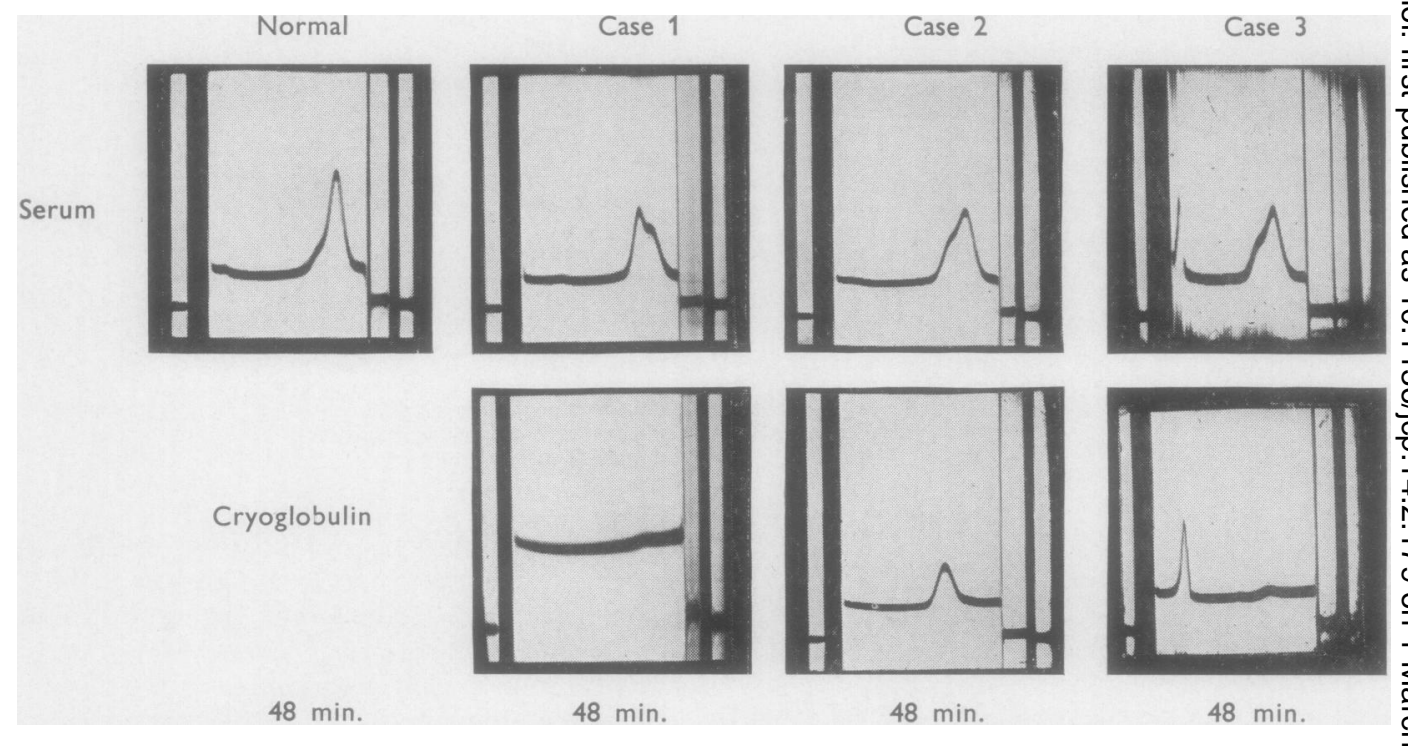

FIG. 2. Ultracentrifugal patterns of whole sera and isolated cryoglobulins. Representative selected patterns at 48 minutBas in each case are shown and compared with the normal.

activity when added to normal serum. The residual serum after removal of the cryoglobulin still possessed some anticomplementary activity. It is concluded that the anticomplementary activity resided in part in the cryoglobulin component.

PRECIPITIN REACTIONS AND IMMUNOELECTROPHORESIS STUDIES The cryoglobulin from Case 1 crossreacted with an antiserum to normal 7S gamma globulin. Immunoelectrophoretically, however, an abnormally shaped precipitin line was obtained (Fig. 3).

The serum from Case 2, when examined by immunoelectrophoresis (Fig. 4), gave a normal and an abnormal gamma globulin precipitin line wi an antiserum to normal $7 \mathrm{~S}$ gamma globulin. The isolated cryoglobulin behaved immunoelectrophoretically in a similar manner to that from Case 1.

Comparative analysis of the cryoglobulin from Case 2 and normal 7S gamma globulin by the Ouchterlony gel-diffusion precipitin technique, usi获 a monospecific antiserum to normal 7S gamma globulin, was carried out. A spur formation of the precipitin line was obtained, (Korngold, 195ब, suggesting that the cryoglobulin is deficient in one or more of the normal gamma globulin determinamt groups and is behaving as an incomplete antigen.

TABLE II

RESULTS OF ULTRACENTRIFUGAL ANALYSES

\begin{tabular}{|c|c|c|c|c|c|c|c|c|c|c|c|c|}
\hline \multirow[t]{3}{*}{ Case } & \multirow[t]{3}{*}{ Specimen } & \multirow{3}{*}{$\begin{array}{l}\text { Total }^{1} \\
\text { Protein } \\
(\mathrm{g} . / 100 \mathrm{ml} .)\end{array}$} & \multicolumn{10}{|c|}{ Concentration of Component $(\mathrm{g} . / 100 \mathrm{ml})}$. \\
\hline & & & \multicolumn{2}{|l|}{$22 S$} & \multicolumn{2}{|l|}{$19 S$} & \multicolumn{2}{|l|}{$10 S$} & \multicolumn{2}{|l|}{75} & \multicolumn{2}{|l|}{$4 \cdot 5 S$} \\
\hline & & & $S_{20, w}$ & $\begin{array}{l}\text { Concen- } \\
\text { tration }\end{array}$ & $S_{\mathbf{2 0}, \mathrm{w}}$ & $\begin{array}{l}\text { Concen- } \\
\text { tration }\end{array}$ & $S_{20, w}$ & $\begin{array}{l}\text { Concen- } \\
\text { tration }\end{array}$ & $S_{\mathbf{2 0}, \mathrm{w}}$ & $\begin{array}{l}\text { Concen- } \\
\text { tration }\end{array}$ & $S_{20, w}$ & $\begin{array}{l}\text { Concen } \\
\text { tration } 0\end{array}$ \\
\hline 1 & $\begin{array}{l}\text { Serum } \\
\text { Cryoglobulin solution }\end{array}$ & $\begin{array}{l}7 \cdot 34 \\
0 \cdot 05\end{array}$ & & & $18 \cdot 8$ & $0 \cdot 16$ & & & 6.5 & $3 \cdot 37$ & $\begin{array}{l}4 \cdot 2 \\
4 \cdot 7\end{array}$ & $\begin{array}{l}3.81 \stackrel{\mathrm{C}}{+} \\
0.05:-\end{array}$ \\
\hline 2 & Serum & $7 \cdot 11$ & & & $19 \cdot 0$ & $0 \cdot 26$ & & & 6.9 & $2 \cdot 30$ & $5 \cdot 0$ & 4.55 \\
\hline & Cryoglobulin solution & $1 \cdot 20$ & & & & & & & $7 \cdot 4$ & 1.08 & $5 \cdot 1$ & $0.12 \overline{0}$ \\
\hline 3 & Serum & $7 \cdot 30$ & $22 \cdot 1$ & $0 \cdot 15$ & $15 \cdot 0^{2}$ & $1 \cdot 70$ & & & $6 \cdot 5$ & $1 \cdot 88$ & $4 \cdot 2$ & 3.57 (D \\
\hline & Cryoglobulin solution & $1 \cdot 00$ & $25 \cdot 5$ & 0.05 & $17 \cdot 4^{2}$ & $0 \cdot 74$ & $9 \cdot 9$ & 0.02 & $6 \cdot 8$ & $0 \cdot 19$ & & \\
\hline
\end{tabular}

${ }^{1}$ Allowance for dilution before ultracentrifugal analysis has been made in calculating the concentrations of the serum components, whereas

concentrations of the cryoglobulin preparations are those of the solutions anlysed.
2The apparently low values for the sedimentation coefficient of the $19 \mathrm{~S}$ component in the serum and cryoglobulin from Case 3 reflect the markedd concentration dependence of this material. 


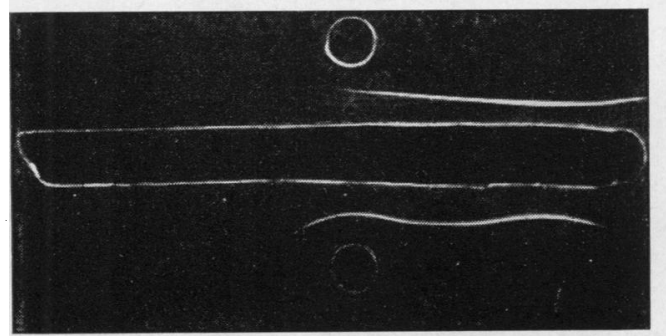

a

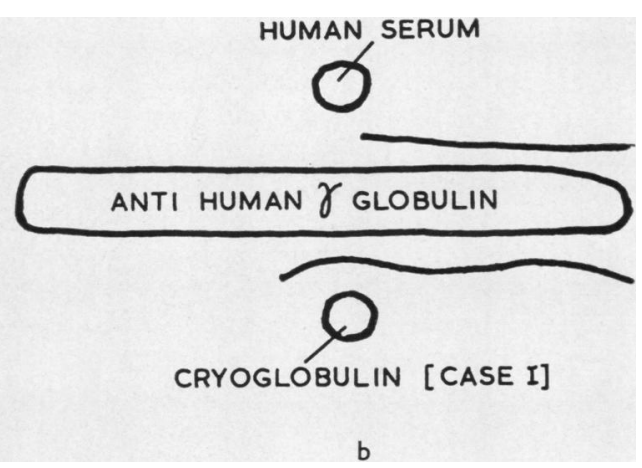

b

FIG. 3. Immunoelectrophoresis of isolated cryoglobulin from Case 1. (a) Illustration of precipitin lines; (b) key. Note the abnormally shaped precipitin line, compared with that usually obtained.

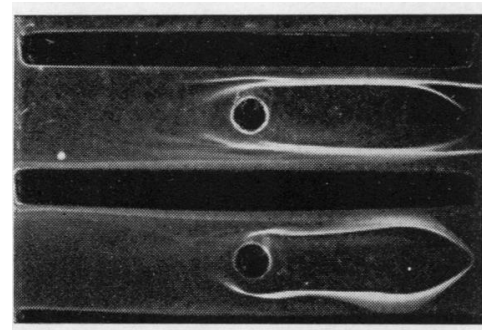

a

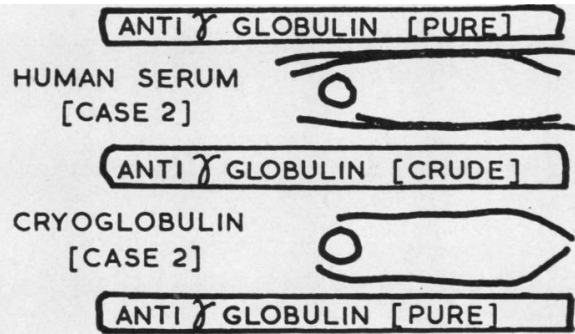

b

FIG. 4. Immunoelectrophoresis of whole serum and isolated cryoglobulin from Case 2. (a) Illustration of precipitin lines; (b) key. Note the two precipitin lines in the $\gamma$ region. One of these is abnormally situated, and appears in the cryoglobulin preparation.

Cryoglobulin II gave no precipitin reaction when tested with the antiserum raised against the cryoglobulin III.

Gel-diffusion precipitin analyses using a specific antiserum against the cryoglobulin from Case 3 supported the physico-chemical evidence that the abnormal protein in this case was an 19S macroglobulin; no reaction was observed when the antiserum was tested either with normal 7S gamma globulin or with the cryoglobulin from Case 2.

\section{DISCUSSION}

Cryoglobulinaemia is not pathognomonic of any single disease entity and may be encountered in a number of diseases of different aetiology, as previously mentioned. In the present three cases the phenomenon was discovered incidentally while sera were being examined for another purpose. In each case there was no evidence to suggest that the cryoglobulinaemia was responsible for any of the clinical features. Thus the symptoms usually associated with the presence of cryoglobulins, such as cold-induced urticaria, and purpuric or thrombotic phenomena, such as digital necrosis or blindness (Hansen and Faber, 1947), were entirely absent. Deliberate attempts to induce cold urticaria by the application of ice to the forearm in Cases 2 and 3 were unsuccessful.

Muirhead, Montgomery, and Gordon (1952) described a case of pulmonary hypertension arising from thrombo-embolism of the pulmonary vessels due to cryoglobulinaemia, and were able to demonstrate histologically the abnormal protein within the thrombi. Histological examination of tissue obtained at necropsy from the present Cases 1 and 3 failed to reveal any convincing evidence of the intravascular deposition of the abnormal proteins.

The present three cases are examples of cryoglobulinaemia occurring secondary to some other recognizable disorder. This is the common type, and that described by Volpé, Bruce-Robertson, Fletcher, and Charles (1956), in which investigation failed to reveal an underlying cause, is relatively uncommon. From a perusal of case reports in the literature, it is clear that the actual concentration of cryoglobulin 
in the serum bears no constant relation to the type or severity of the clinical manifestations; large amounts of the abnormal protein may be present in the absence of symptoms attributable to it, and conversely, marked symptoms may occur when only low concentrations of cryoglobulin are detectable.

It is of interest that one of the present patients was suffering from polyarteritis nodosa, since the association has previously been noted (see references above). We have examined the sera from two other cases of polyarteritis nodosa, with negative results.

The physico-chemical properties of the cryoglobulins appear to vary considerably. Although the present three cryoglobulins had similar electrophoretic mobilities, and behaved as $\gamma$ globulins, the ultracentrifugal analysis revealed marked differences in their individual properties. It is usual for cryoglobulins to behave like normal serum $\gamma$ globulin when examined by the technique of paper electrophoresis, although mobilities ranging from that of $\alpha_{2}$ globulin to that of $\gamma_{2}$ globulin have been described (see Mackay et al., 1956, for references). Ultracentrifugally, the cryoglobulin from Case 2 was indistinguishable from normal $\gamma$ globulin, whereas that from Case 3 behaved as a macroglobulin. This phenomenon of ail abnormal protein having the properties of a cryoglobulin and a macroglobulin has been observed previously, for example, by McFarlane, Dorey, Slack, and Papastamatis (1952) and by Petermann and Braunsteiner (1954) in the case of a cryoglobulin occurring in serum, and by Abrams, Cohen, and Meyer (1949) in the case of a cryoglobulin isolated from the lymph nodes removed from a patient suffering from lymphosarcoma.

It seems likely that the cryoglobulins are abnormal protein constituents of human serum, and do not represent an increase in the concentration of components normally present only in trace amounts. This appears to be supported by the results of the immunological analyses carried out on the present three cryoglobulins. Thus cryoglobulins in Cases 2 and 3 show immunological characteristics which readily distinguish them from each other and from normal 7S $\gamma$ globulin.
This conclusion is consistent with the results structural studies on abnormal human seru再 globulins carried out by Putnam (1958), who demonstrated that multiple myeloma globulins, macroglobulins, and cryoglobulins can be disti guished from each other and from normal $\gamma$ globu䅦 by their $\mathrm{N}$-terminal residues, as well as by their physico-chemical properties.

We are indebted to Drs. W. T. Cooke, C. F. Hawkins, and P. Davison for permission to publish details comp cerning their patients, to Professor J. R. Squire for help뼈 criticism, and to Professor P. Gell for making availate certain data concerning the immunological aspects of the study. One of us (H.A.E.) was in receipt of a grant from the United Birmingham Hospitals Endowment Fund when the study was undertaken.

\section{REFERENCES}

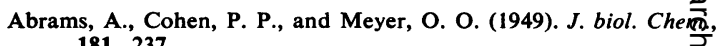
181, 237. Atlas, D. H., Cardon, L., and Bunata, J. (1943). Amer. J. clin. Paஜb,

Butler, K. R., and Palmer, J. A. (1955). Canad. med. Ass. J., 72, 6896 Cooke, W. T., and French, J. M. (1958). In Modern Trends in Gast enterology (Second Series), ed. F. Avery Jones, p. 219. Butterworths, London.

Dreyfuss, F. (1953). Acta. med. Orient. (Tel-Aviv), $12,319$.

Grabar, P., and Williams, C. A. (1955). Biochim. Biophys. Acta, $\overline{\bar{B}}$, 67.

Gunz, F. W. (1956). Brit. J. Haemat., 2, 95.

Hansen, P. F., and Faber, M. (1947). Acta med. scand., 129, 81.

Hardwicke, J. (1954). Biochem. J., 57, 166.

Korngold, L. (1956). J. Immunol., 77, 119.

Lepow, H., Rubenstein, L., Woll, F., and Greisman, H. (1949) Amer. J. Med., 7, 310.

Lerner, A. B., and Watson, C. J. (1947). Amer. J. med. Sci., 214, 4 ठే.

Mackay, I. R., Eriksen, N., Motulsky, A. G., and Volwiler, W. (1956). Amer. J. Med., 20, 564.

McFarlane, A. S., Dorey, A., Slack, H. G. B., and Papastamatis, S. (1952). J. Path. Bact., 64, 335.

Muirhead, E. E., Montgomery, P. O' B., and Gordon, C. E. (1953) Arch. intern. Med., 89, 41.

Petermann, M. L., and Braunsteiner, H. (1954). Arch. Bioche? Biophys., 53, 491.

Putnam, F. W. (1958). J. biol. Chem., 233, 1448.

Shapiro, B., and Wertheimer, E. (1946). Brit. J. exp. Path., 27, 2 인.

Volpé, R., Bruce-Robertson, A., Fletcher, A. A., and Charles, W. B. (1956). Amer. J. Med., 20, 533.

Walton, K. W., and Ellis, H. A. (1958). Immunology, 1, 224.

Wertheimer, E., and Stein, L. (1944). J. Lab. clin. Med., 29, 1082 . N

Wintrobe, M. M., and Buell, M. V. (1933). Johns Hopk, Hosp. Buf?, 52, 156. 